\title{
Erratum to: Cardiac resuscitation in the operating room: Reflections on how we can do better
}

\author{
William R. Berry, MD
}

Published online: 30 June 2012

(c) Canadian Anesthesiologists' Society 2012

Erratum to: Can J Anesth/J Can Anesth (2012) 59:522-526

DOI 10.1007/s12630-012-9697-5

In the editorial entitled: "Cardiac resuscitation in the operating room: Reflections on how we can do better" published in the June 2012 issue, Can J Anesth 2012; DOI: $10.1007 / \mathrm{s} 12630-012-9697-5$, the authors mentioned in the text as "Charapov and Naveen" should read "Charapov and Eipe". The publisher apologizes for this error.

The online version of the original article can be found under doi: 10.1007/s12630-012-9697-5.

W. R. Berry, MD ( $\square)$

Department of Health Policy and Management, Harvard School of Public Health, 677 Huntington Avenue, Boston, MA 02115, USA

e-mail: wberry@hsph.harvard.edu 